\title{
A COMPARATIVE STUDY OF THE PASSIVATION AND LOCALIZED CORROSION OF $\alpha$-BRASS AND $\beta$-BRASS IN BORATE BUFFER SOLUTIONS CONTAINING SODIUM CHLORIDE: III. THE EFFECT OF TEMPERATURE
}

\author{
J. MORALES, ${ }^{a}$ G. T. FERNANDEZ, ${ }^{a}$ S. GONZALEZ, ${ }^{a}$ P. ESPARZA, ${ }^{a *}$ \\ R. C. SALVAREZZA ${ }^{b}$ and A. J. ARVIA ${ }^{b} \dagger$ \\ ${ }^{a}$ Departamento de Química Física, Universidad de La Laguna, Tenerife, Spain \\ ${ }^{\text {b} I n s t i t u t o ~ d e ~ I n v e s t i g a c i o n e s ~ F i s i c o q u i ́ m i c a s ~ T e o ́ r i c a s ~ y ~ A p l i c a d a s ~(I N I F T A), ~ S u c u r s a l ~ 4, ~ C a s i l l a ~ d e ~ C o r r e o ~ 16, ~}$ \\ (1900) La Plata, Argentina

\begin{abstract}
The passivation and localized corrosion of $\alpha$-brass and $\beta$-brass in an aqueous borate-boric acid buffer (pH 9) containing different concentrations of $\mathrm{NaCl}\left(c_{\mathrm{NaCl}}\right)$ in the temperaturc range $5^{\circ} \mathrm{C} \leq T \leq 45^{\circ} \mathrm{C}$ werc studicd comparatively by potential sweeping at $2 \times 10^{-2} \mathrm{~V} \mathrm{~s}^{-1}$ and $2 \times 10^{-4} \mathrm{~V} \mathrm{~s}^{-1}$ and de-alloying measurements. The passivation of $\alpha$-brass and $\beta$-brass was related to the electroformation of a complex $\mathrm{ZnO} \cdot x \mathrm{H}_{2} \mathrm{O} / \mathrm{Cu}_{2} \mathrm{O}$ layer, its thickness and compactness presumably increasing with temperature. For both $\alpha$-brass and $\beta$-brass immersed in an aqueous NaCl-containing buffer, pitting corrosion was observed as the value of the breakdown potential $\left(E_{\mathrm{b}}\right)$ was exceeded. At constant temperature, the value of $E_{\mathrm{b}}$ shifted negatively as either $c_{\mathrm{NaCl}}$ or the zinc content in the alloy was increased. For $\beta$-brass, the value of $E_{\mathrm{b}}$ decreased slightly with increasing temperature in the range $5^{\circ} \mathrm{C} \leq T \leq 45^{\circ} \mathrm{C}$. In the range $5^{\circ} \mathrm{C} \leq T \leq 25^{\circ} \mathrm{C}$, for $\alpha$-brass the value of $E_{\mathrm{b}}$ was close to that reported for copper, whereas for $T>25^{\circ} \mathrm{C}$ it approached those values measured for $\beta$-brass. De-alloying measurements in aqueous $0.5 \mathrm{M} \mathrm{NaCl}$ indicate that zinc surface enrichment of $\alpha$-brass was responsible for the decrease in pitting corrosion resistance at $T>45^{\circ} \mathrm{C}$. (C) 1998 Elsevier Science Ltd. All rights reserved
\end{abstract}

Keywords: A. brass, C. passive films, C. localized corrosion.

\section{INTRODUCTION}

The electrochemical behaviour of $\mathrm{Cu}-\mathrm{Zn}$ alloys (brass) has been studied extensively over a wide range of experimental conditions in relation to dezincification and stress corrosion cracking ${ }^{1-3}$ and, more recently, passivation and pitting corrosion. ${ }^{46}$ In neutral and alkaline solutions the passivation of brass involves the electroformation of a complex $\mathrm{ZnO} \cdot x \mathrm{H}_{2} \mathrm{O}$ and $\mathrm{Cu}_{2} \mathrm{O}$ layer, as concluded from electrochemical, $\mathrm{X}$-ray photoelectron spectroscopy and Auger spectroscopy data. ${ }^{7}$ In general, passivity breakdown depends strongly on the composition of the alloy, the aggressive environment and temperature.

The breakdown potential $\left(E_{\mathrm{b}}\right)$ of $\alpha$-brass, $\beta$-brass and $\alpha+\beta$-brass in chloride-containing

*Present address: Departamento de Química Inorganica, Universidad de La Laguna, Tenerife, Spain.

$\nmid$ To whom correspondence should be addressed.

Manuscript received 3 May 1997 
buffers shifts negatively as the $\mathrm{Cu} / \mathrm{Zn}$ ratio in the alloy decreases, ${ }^{6}$ although $E_{\mathrm{b}}$ is hundreds of $\mathrm{mV}$ more positive than that of zinc owing to the formation of a copper-enriched surface layer. ${ }^{6}$ On the other hand, the increase in $\mathrm{NaCl}$ concentration $\left(c_{\mathrm{NaCl}}\right)$ produces a substantial decrease in the potential range of passivity, promoting pitting corrosion. ${ }^{6}$ However, in contrast to other metals and alloys, little is known about the influence of temperature on the passivation and pitting corrosion of brass.

This work refers to a comparative study of the passivation and pitting corrosion of $\alpha$ brass and $\beta$-brass in an aqueous $\mathrm{NaCl}$-containing borate-boric acid buffer in the temperature range $5^{\circ} \mathrm{C} \leq T \leq 45^{\circ} \mathrm{C}$. At a given $\mathrm{NaCl}$ concentration, the value of $E_{\mathrm{b}}$ for $\beta$-brass decreases slightly as the temperature is increased. For $\alpha$-brass, in the range $5^{\circ} \mathrm{C} \leq T \leq 25^{\circ} \mathrm{C}$, the value of $E_{\mathrm{b}}$ is close to that reported previously for copper, ${ }^{8}$ for $T>25 \mathrm{C}$ it diminishes, approaching that observed for $\beta$-brass. This fact can be explained by the enhancement of electrodissolution of copper from the alloy as the temperature is increased above $25 \mathrm{C}$.

\section{EXPERIMENTAI. METHOD}

Working electrodes (specimens) were made from rods of $\alpha$-brass and $\beta$-brass, with the following chemical composition: $71.719 \% \mathrm{Cu}, 28.228 \% \mathrm{Zn}, 0.011 \% \mathrm{C}, 0.008 \% \mathrm{Al}, 0.031 \%$ $\mathrm{Sn}, 0.001 \%$ As for $\alpha$-brass, and $54.700 \% \mathrm{Cu}, 45.240 \% \mathrm{Zn}, 0.026 \% \mathrm{C}, 0.005 \% \mathrm{Al}, 0.023 \%$ $\mathrm{Sn}, \mathrm{As}$ and $\mathrm{Si}<0.001$ for $\beta$-brass.

Brass rods were made by melting and casting known amounts of copper $(99.999 \%)$ and zinc $(99.999 \%)$. Drawn brass bars $0.6 \mathrm{~cm}$ in diameter were machined to obtain cylindrical specimens $0.3 \mathrm{~cm}$ in diameter. Specimens were mounted vertically and the base of each cylinder was used as a horizontal disc working electrode in contact with a hanging column of the electrolyte solution. ${ }^{9}$ The working electrode (specimen) was wet polished with emery papers of different grain size and finished with $1 \mu \mathrm{m}$ grit alumina paste. Subsequently, each specimen was cleaned ultrasonically, rinsed successively with distilled acetone and doubly distilled water, and dried in air at room temperature. Finally, specimens were lodged under argon in Pyrex tubing, and thermally treated at $150 \mathrm{C}$ for $2 \mathrm{~h}$ to eliminate residual mechanical stresses and improve surface uniformity. This pretreatment led to good reproducibility of the results.

Electrochemical runs were made in quiescent aqueous $0.075 \mathrm{M} \mathrm{Na}_{2} \mathrm{~B}_{4} \mathrm{O}_{7}+0.15 \mathrm{M} \mathrm{H}_{3} \mathrm{BO}_{3}$ $(\mathrm{pH} 9)$, with and without the addition of aqueous $x \mathrm{M} \mathrm{NaCl}(0.05 \leq x \leq 0.5)$, covering the temperature range $5 \mathrm{C}<T<45 \mathrm{C}$. Occasionally. solutions under stirring conditions were employed to explore possible diffusion-controlled processes from the solution side. A conventional three-electrode Pyrex glass cell was used including the specimen, the reference electrode and a platinum wire counter electrode. The potential applied to the working electrode was measured against a saturated calomel electrode (SCE) provided with a Luggin-Haber capillary tip. All potentials in the text are referred to the saturated calomel electrode at $T=25^{\circ} \mathrm{C}$. For this purpose, the following equation was employed ${ }^{8}$

$$
E / \mathrm{V}=0.2421-6.61 \times 10^{-4}(T-25)-1.75 \times 10^{-6}(T-25)^{2}
$$

Conventional triangular potential sweep voltammetry was run at $v=2 \times 10^{-2} \mathrm{~V} \mathrm{~s}^{-1}$ and at $v=2 \times 10^{-4} \mathrm{Vs}^{-1}$ starting from the cathodic switching potential, $E_{\mathrm{cs}}$, to the anodic switching potential, $E_{\mathrm{as}}$. At the lowest value of $t$, the behaviour of voltammograms closely approached that of potentiostatic polarization curves. 
The amount of soluble species produced during the anodic polarization of specimens was determined by atomic absorption spectroscopy.

\section{EXPERIMENTAL RESULTS AND INTERPRETATION}

Voltammetric data of $\alpha$-brass and $\beta$-brass in a $\mathrm{NaCl}$-free boric buffer

Voltammograms run with $\alpha$-brass specimens at different temperatures between $E_{\mathrm{cs}}$ and $E_{\text {as }}$ (Fig. 1) exhibit peaks $\mathrm{AI}$ and $\mathrm{AI}^{\prime}$ at $-1.2 \mathrm{~V}$ and $-0.75 \mathrm{~V}$, respectively, related to electroformation of $\mathrm{ZnO} \cdot x \mathrm{H}_{2} \mathrm{O}$, and peaks $\mathrm{CI}$ at $-1.3 \mathrm{~V}$ and $\mathrm{CI}^{\prime}$ at $-0.90 \mathrm{~V}$ related mainly to the electroreduction of $\mathrm{ZnO} \cdot x \mathrm{H}_{2} \mathrm{O}$ and partly to the electroreduction of $\mathrm{Zn}$ (II)

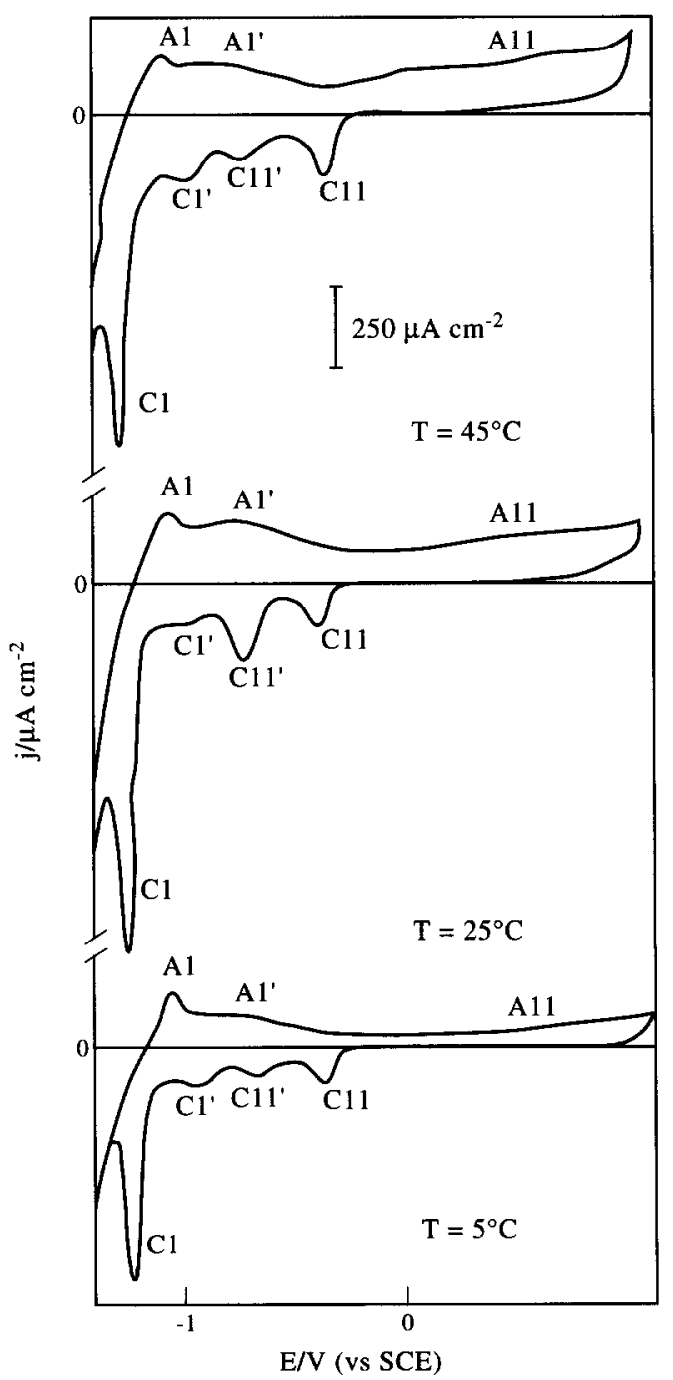

Fig. 1. Voltammograms of $\alpha$-brass in a borate-boric acid buffer run at $0.02 \mathrm{Vs}^{-1}$ at different temperatures. 
soluble species produced in the preceding half-cycle in the potential range of peaks AI$\mathrm{Al}^{\prime}{ }^{6} .10$

The contribution of the electroformation of $\mathrm{Cu}_{2} \mathrm{O}$ species to the anodic layer can bc observed when the applied potential $(E)$ exceeds $-0.25 \mathrm{~V}$, i.e. in the region of peak AII, ${ }^{6,11}$ whereas the electro-oxidation of $\mathrm{Cu}_{2} \mathrm{O}$ to $\mathrm{CuO}$ takes place at $E>0.25 \mathrm{~V}$. Otherwise, the electroreduction of $\mathrm{CuO}$ to $\mathrm{Cu}_{2} \mathrm{O}$ occurs in the range $-0.25 \mathrm{~V}>E>-0.40 \mathrm{~V}$ (peak CII), whereas the electroreduction of $\mathrm{Cu}(\mathrm{I})$ species to $\mathrm{Cu}$ occurs in the range $-0.5 \mathrm{~V}>E>-0.8 \mathrm{~V}$ (peak $\mathrm{CII}^{\prime}$ ), overlapping to some extent the electroreduction of $\mathrm{Zn}(\mathrm{II})$ species at $\mathrm{CI}^{\prime}$.

The overall voltammetric charge $(q)$, particularly that involved at low values of $E$, increases with temperature. From these voltammograms it can be concluded that the anodic layer formed at $E>-0.25 \mathrm{~V}$ consists of copper oxides and $\mathrm{ZnO} \cdot x \mathrm{H}_{2} \mathrm{O}$. It should be noted that the value of $x$ determining the water content of the zinc oxide layer decreases as temperature is increased, as the $\mathrm{Zn}(\mathrm{OH})_{2}$ species is easily dehydrated approaching the $\mathrm{ZnO}$ stoichiometry. ${ }^{12}$

Solution stirring produces no marked changes in the above mentioned voltammograms, at least in the potential range of peaks $\mathrm{AI}-\mathrm{AI}^{\prime}$ and $\mathrm{CI}-\mathrm{CI}^{\prime}$. Therefore, the electrochemical reactions associated with these peaks can be principally assigned to the processes taking place on the specimen surface, either solid phase formation or disappearance, respectively. Then, for $E>-0.7 \mathrm{~V}$, the voltammetric electro-oxidation charge is largely stored as a $\mathrm{ZnO} \cdot x \mathrm{H}_{2} \mathrm{O}$ layer on $x$-brass. The decrease in the anodic current at $E>-0.5 \mathrm{~V}$ is related to the increase in average thickness of the $\mathrm{ZnO} \cdot x \mathrm{H}_{2} \mathrm{O}$ layer.

The preceding description is qualitatively similar for all voltammograms run in the range $5{ }^{\circ} \mathrm{C} \leq T \leq 45^{\circ} \mathrm{C}$. From a quantitative standpoint, on increasing temperature, current peaks are better defined and the corresponding charges are increased. In this case, the contribution of the background current related to electrodeposition of zinc at $E<-1.0 \mathrm{~V}$ can also be observed.

Voltammograms of $\beta$-brass specimens in either still or stirred solutions run in the same range of temperature (Fig. 2) are qualitatively similar to those described above for $\alpha$-brass, although for $\beta$-brass the formation and electroreduction charges involving $\mathrm{Zn}(\mathrm{OH})_{2}$ and $\mathrm{Zn}(\mathrm{II})$-containing species are relatively greater than the charge involved in the electroreduction and electroformation of copper oxide species.

Similarly to $\alpha$-brass, the shape of the voltammetric profiles for $\beta$-brass does not change appreciably on increasing the temperature, although a net increase in the voltammetric charge related to the electroformation and electroreduction of zinc and copper oxides can be observed. This fact suggests that the anodic layer becomes thicker or more compact on increasing the temperature.

\section{Voltammetric data from $\mathrm{NaCl-containing} \mathrm{borate} \mathrm{buffers}$}

Voltammograms of $\alpha$-brass (Fig. 3) and $\beta$-brass (Fig. 4) were run at different temperatures in an aqueous $0.5 \mathrm{M} \mathrm{NaCl}$-containing buffer covering values of $E_{\mathrm{as}}$ lower than $E_{\mathrm{h}}$ to avoid the interference of pitting corrosion in the electroformation of the anodic layer. Processes related to the electroformation and electroreduction of $\mathrm{ZnO} \cdot x \mathrm{H}_{2} \mathrm{O}$ and soluble $\mathrm{ZnCl}^{-}$species are clearly observed in the potential range $-1.2 \mathrm{~V} \leq E \leq E_{\mathrm{b}}$. As these voltammograms are similar to those observed for the plain buffer, it appears that in this case the anodic layer also consists of a $\mathrm{ZnO} \cdot x \mathrm{H}_{2} \mathrm{O}$ layer on a copperenriched surface. Accordingly, as observed in the plain borate-boric acid buffer, the 


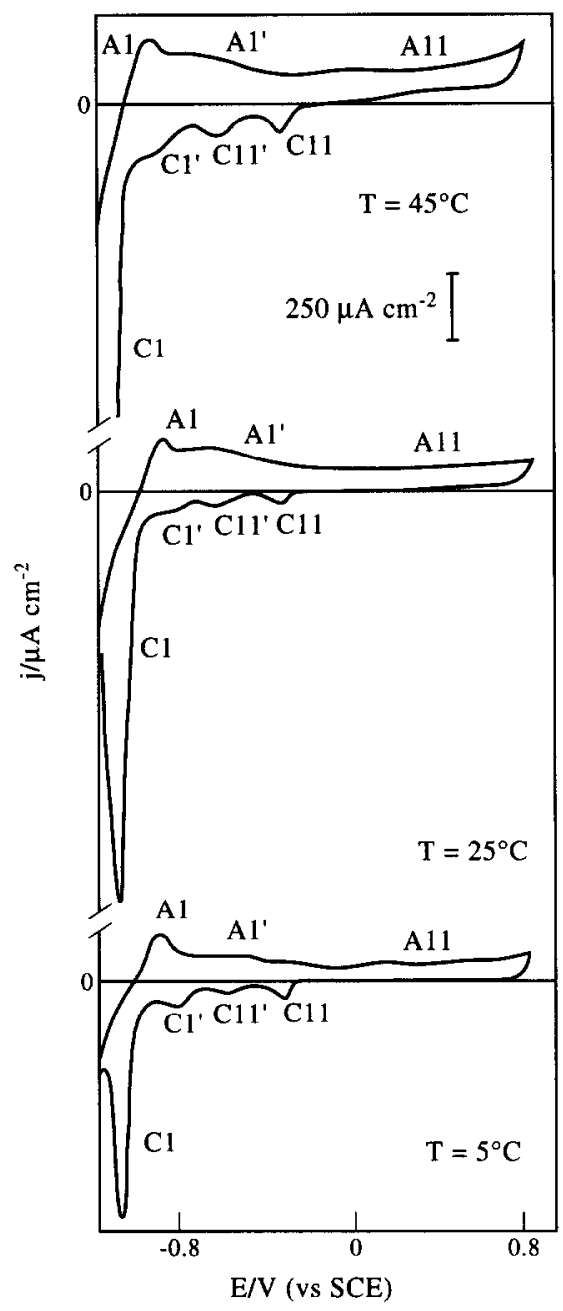

Fig. 2. Voltammograms of $\beta$-brass in a borate-boric acid buffer run at $0.02 \mathrm{~V} \mathrm{~s}^{-1}$ at different temperatures.

increase in temperature in this case results in the charge increase of peaks $\mathrm{AI}$ and $\mathrm{AI}^{\prime}$ which are related to the electroformation of $\mathrm{ZnO} \cdot x \mathrm{H}_{2} \mathrm{O}$ and $\mathrm{Zn}$ (II) soluble species.

\section{Pitting corrosion potential measurements}

For both $\alpha$-brass and $\beta$-brass, values of $E_{\mathrm{b}}$ were determined from anodic polarization curves recorded from $-1.3 \mathrm{~V}$ upwards at $v=2 \times 10^{-4} \mathrm{~V} \mathrm{~s}^{-1}$ in a buffer solution containing either $5 \times 10^{-2} \mathrm{M} \mathrm{NaCl}$ or $0.5 \mathrm{M} \mathrm{NaCl}$, covering the range $5^{\circ} \mathrm{C} \leq T \leq 45^{\circ} \mathrm{C}$ (Fig. 5). The value of $E_{\mathrm{b}}$ was defined as the most positive potential where the anodic current still remains in the 'passivity range'. The polarization curve for $\alpha$-brass recorded at $5^{\circ} \mathrm{C}$ comprises the formation of a rather smaller amount of $\mathrm{Zn}$ (II) species, and a relatively larger amount of $\mathrm{Cu}(\mathrm{II})$ species. Furthermore, in this case, the value of $E_{\mathrm{b}}$ is more positive than that observed for $\beta$-brass. When temperature is increased from $5^{\circ} \mathrm{C}$ to 


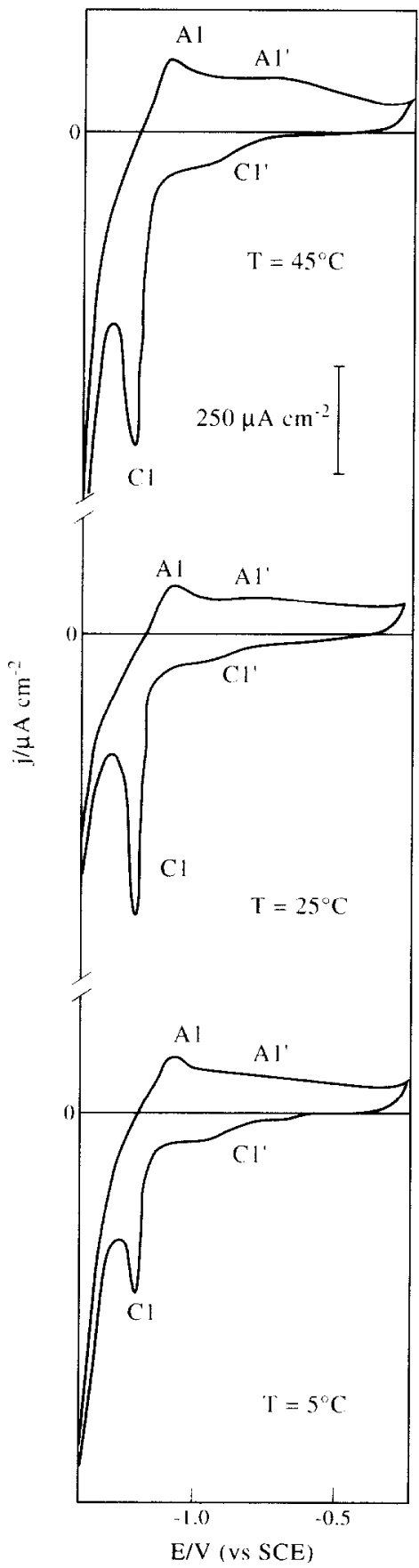

Fig. 3. Voltammograms of $\alpha$-brass in a $0.5 \mathrm{M} \mathrm{NaCl-containing} \mathrm{borate-boric} \mathrm{acid} \mathrm{butfer} \mathrm{run} \mathrm{at}$ $0.02 \mathrm{~V} \mathrm{~s}^{-1}$ at different temperatures. 


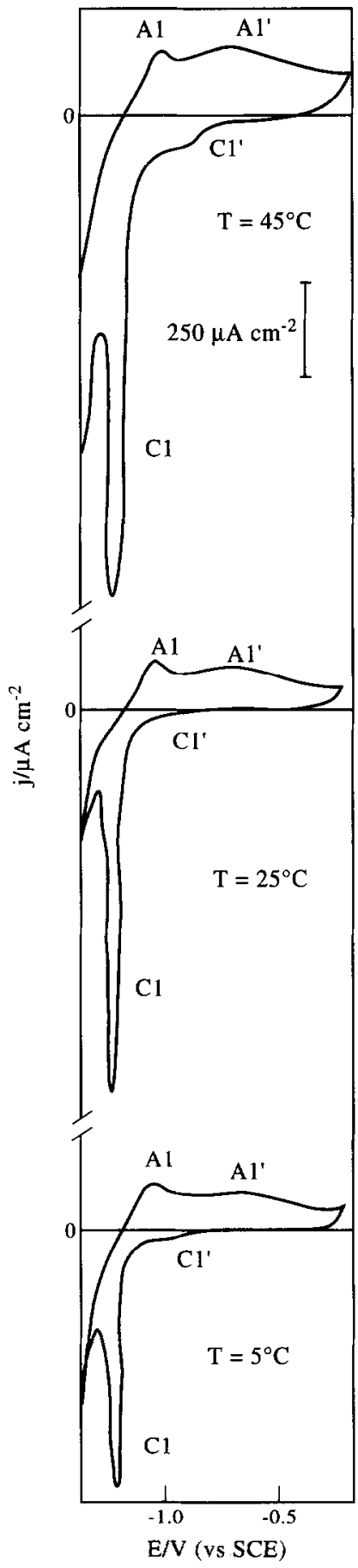

Fig. 4. Voltammograms of $\beta$-brass in a $0.5 \mathrm{M} \mathrm{NaCl}$-containing borate-boric acid buffer run at $0.02 \mathrm{~V} \mathrm{~s}^{-1}$ at different temperatures 

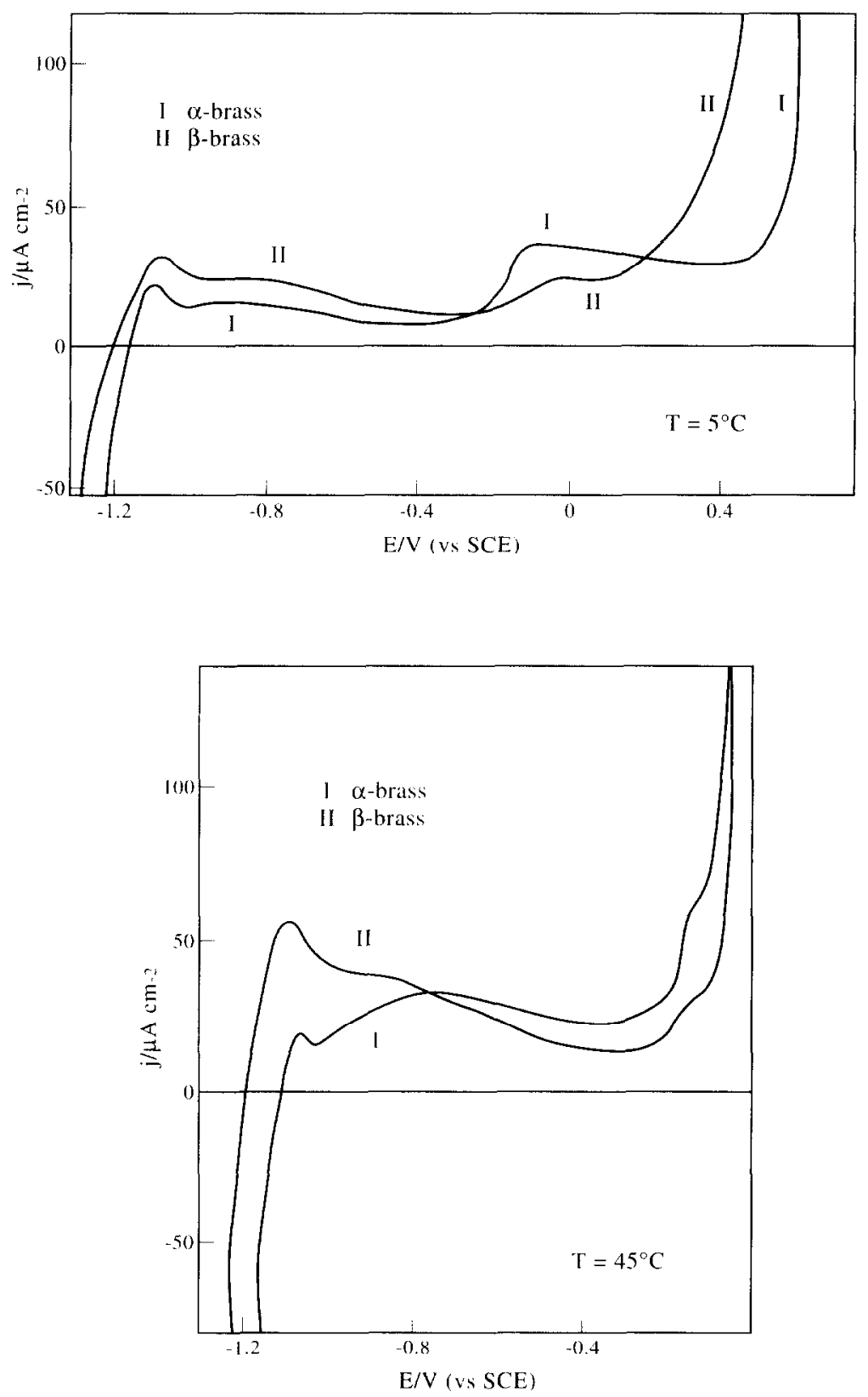

Fig. 5. Anodic polarization curves of $\alpha$-brass and $\beta$-brass in a $0.5 \mathrm{M} \mathrm{NaCl}$-containing borateboric acid buffer run at $2 \times 10^{-4} \mathrm{Vs}$ ' and different temperatures.

$45 \mathrm{C}$, the values of $E_{\mathrm{b}}$ for both $\alpha$-brass and $\beta$-brass move negatively, although at $45 \mathrm{C}$, the values of $E_{\mathrm{b}}$ for both specimens tend to be very close to each other. However, as usually observed for other systems, ${ }^{13}$ the values of $E_{\mathrm{b}}$ are scattered in a rather broad 
potential range so that a statistical analysis of $E_{\mathrm{b}}$ is needed. In this case, it is useful to define the probabilitiy $\left(P_{n} \geq 1\right)$ of forming at least one stable pit at the potential $E$, as: ${ }^{13}$

$$
P_{n} \geq_{1}=N(E) / N_{\mathrm{t}}
$$

where $N(E)$ is the number of specimens that develop pitting at a given $E$ in the pitting potential range, and $N_{\mathrm{t}}$ is the total number of specimens. The cumulative $\left(P_{n} \geq 1\right)$ vs. $E$ plots derived from the anodic polarization curves for $\alpha$-brass and $\beta$-brass in aqueous $\mathrm{NaCl}$-containing buffers at $5^{\circ} \mathrm{C}$ and $45^{\circ} \mathrm{C}$ (Fig. 6) indicate that the range of potential related to pitting corrosion becomes relatively broad and shifts positively as either the copper content in the alloy is increased or $c_{\mathrm{NaCl}}$ is diminished. On the other hand, for $\alpha$-brass, at a constant $c_{\mathrm{NaCl}}$, the value of $E_{\mathrm{b}}$ decreases slightly in the range $5^{\circ} \mathrm{C} \leq T \leq 25^{\circ} \mathrm{C}$,
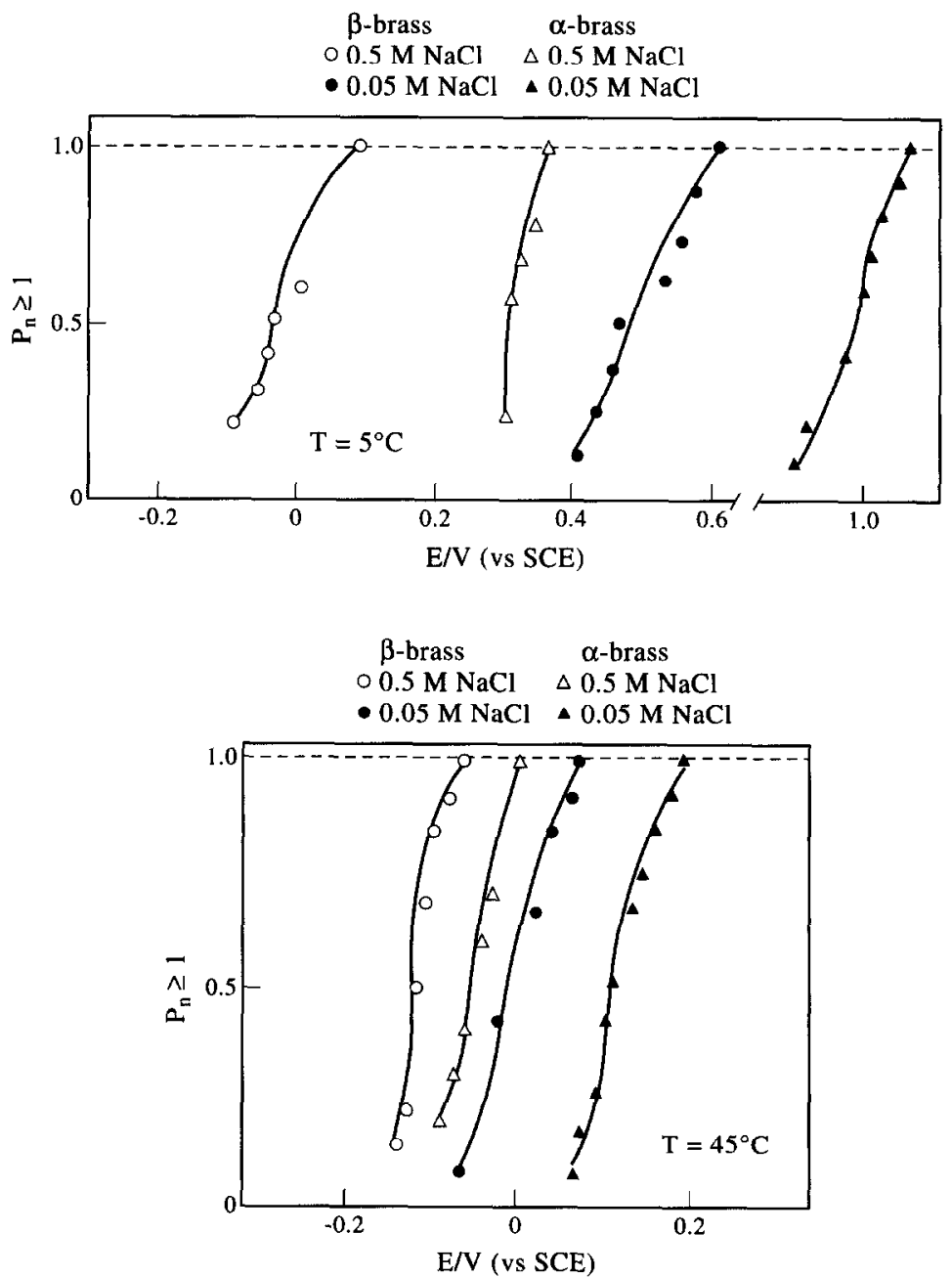

Fig. 6. $P_{n} \geq 1$ vs. $E$ plots resulting from polarization curves for $\alpha$-brass and $\beta$-brass in a $\mathrm{NaCl}$ containing borate-boric acid buffer at different $\mathrm{NaCl}$ concentrations: (a) $T=5^{\circ} \mathrm{C}$; (b) $T=45^{\circ} \mathrm{C}$. 


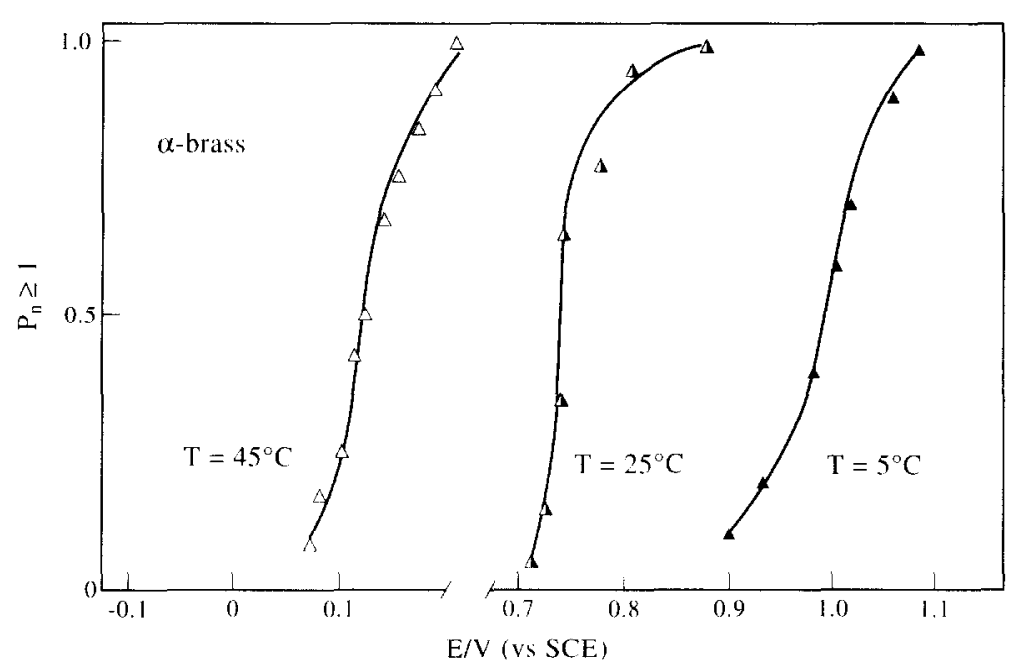

Fig. 7. $P_{n} \geq 1$ vs. E plots resulting from polarization curves of $\alpha$-brass in a $0.05 \mathrm{M} \mathrm{NaCl-containing}$ borate boric acid buffer at different temperatures.

whereas it exhibits a substantial decrease for $T>25 \mathrm{C}$ (Fig. 7 ). For $\beta$-brass the value of $E_{b}$ remains practically constant in the range $5 \mathrm{C} \leq T \leq 25^{\circ} \mathrm{C}$, and decreases slightly for $T>25 \mathrm{C}$, irrespective of $\mathrm{C}_{\mathrm{NaC}}$.

If the average pitting potential value $\left(\left\langle E_{\mathrm{b}}\right\rangle\right)$ is that corresponding to $P_{n} \geq 1=50 \%$, a plot of $\left\langle E_{\mathrm{b}}\right\rangle$ vs. $T$ for both $\alpha$-brass and $\beta$-brass in aqueous $0.5 \mathrm{M}$ and $0.05 \mathrm{M} \mathrm{NaCl}-$ containing buffers (Fig. 8) enables values of $\left\langle E_{\mathrm{b}}\right\rangle$ to be compared with those resulting from polycrystalline copper and zinc specimens in the same solutions. These plots clearly show that for $\alpha$-brass the value of $E_{\mathrm{b}}$ lies close to that of copper ${ }^{8}$ only in the range $5 \mathrm{C} \leq T \leq 25 \mathrm{C}$, but it is definitely much smaller for $T>25 \mathrm{C}$. For $\beta$-brass, $\left\langle E_{\mathrm{b}}\right\rangle$ remains nearly the same in the range $5 \mathrm{C} \leq T \leq 25^{\circ} \mathrm{C}$, and approaches that of $\alpha$-brass for $T>25^{\circ} \mathrm{C}$. Otherwise, for $\beta$-brass, at constant temperature, the value of $\left\langle E_{\mathrm{b}}\right\rangle$ is always more negative than that for copper in the same solution because of the low copper content in $\beta$-brass. In any case, the value of $\left\langle E_{\mathrm{b}}\right\rangle$ is hundreds of $\mathrm{mV}$ more positive than the value of $\left\langle E_{\mathrm{h}}\right\rangle$ for polycrystalline zinc in the range of temperature covered by this work.

It is interesting to note that the difference between $\left\langle E_{\mathrm{b}}\right\rangle$ values of $\alpha$-brass and $\beta$ brass tends to disappear at $45 \mathrm{C}$, i.e. $\alpha$-brass behaves as an alloy with low copper content. In principle, this can be related to changes in the surface composition of the alloy produced at this tempcrature during alloy electrodissolution.

\section{De-alloying of $\alpha$-brass and $\beta$-brass in $0.5 \mathrm{M} \mathrm{NaCl}$ at different temperatures}

The anodic polarization curves of $\alpha$-brass and $\beta$-brass in $0.5 \mathrm{M} \mathrm{NaCl}$ at $5 \mathrm{C}$ and $45 \mathrm{C}$ (Fig. 9) exhibit a broad potential region where $\mathrm{Zn}(\mathrm{II})$ soluble species are produced through a thin $\mathrm{ZnO} \cdot x \mathrm{H}_{2} \mathrm{O}$ layer. ${ }^{14}$ At constant temperature, this potential region moves positively as the zinc content in the alloy decreases, whereas the electrodissolution current increases with temperature. The selective electrodissolution of zinc extends from 


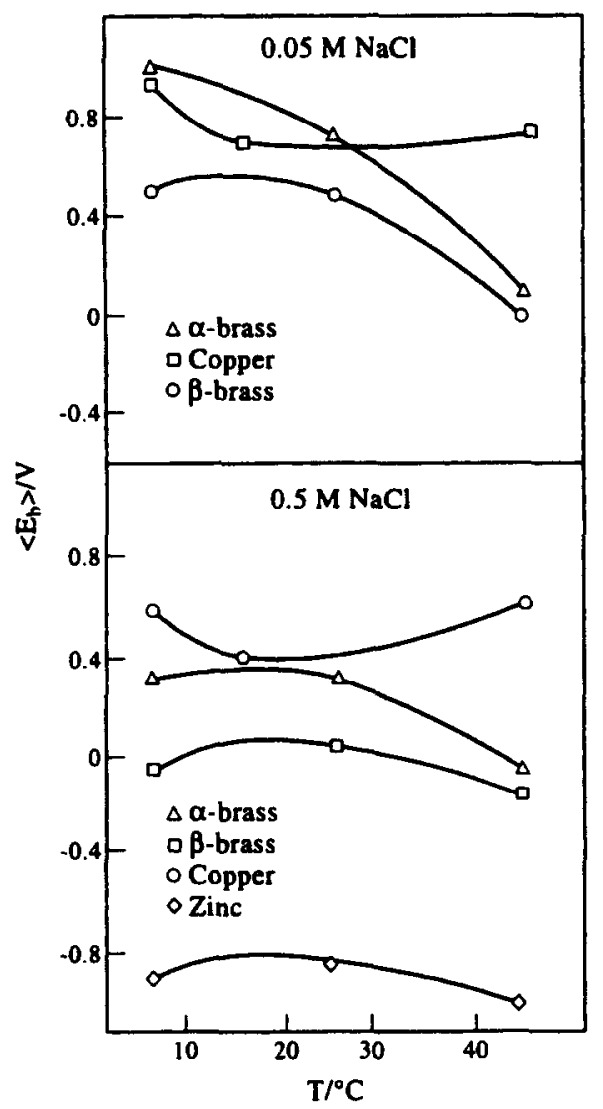

Fig. 8. $\quad E_{\mathrm{b}}$ vs. $T$ plots for $\alpha$-brass, $\beta$-brass, copper and zinc in a borate boric acid buffer containing different $\mathrm{NaCl}$ concentrations.

$E \cong-1.1 \mathrm{~V}$ to $-0.4 \mathrm{~V}$, whereas the simultaneous electrodissolution of both zinc and copper takes place from $E>-0.4 \mathrm{~V},{ }^{14}$ producing a considerable increase in current.

Polarization curves clearly indicate that in the potential range where pitting corrosion of $\alpha$-brass and $\beta$-brass is observed in the aqueous $\mathrm{NaCl}$-containing buffer, the electrodissolution of both components produces changes in the surface composition of the alloy which can be followed by the determination of dissolved copper and zinc.

\section{Atomic absorption measurements}

The preferential electrodissolution of zinc was achieved by holding the specimens for $3 \mathrm{~h}$ at $E=0.0 \mathrm{~V}$ in aqueous $0.5 \mathrm{M} \mathrm{NaCl}$ at different temperatures, the amounts of soluble copper and zinc species subsequently being determined by atomic absorption spectroscopy analysis. These results are shown in Table 1.

Results assembled in Table 1 indicate that, in the range $5^{\circ} \mathrm{C} \leq T \leq 25^{\circ} \mathrm{C}, \alpha$-brass in aqueous $0.5 \mathrm{M} \mathrm{NaCl}$ undergoes milder corrosion than $\beta$-brass, but for $T=45^{\circ} \mathrm{C}$ the corrosion behaviour of $\alpha$-brass in this solution approaches that of $\beta$-brass.

For both alloys, the $\mathrm{Cu} / \mathrm{Zn}$ ratio in the solution remains constant in the range 

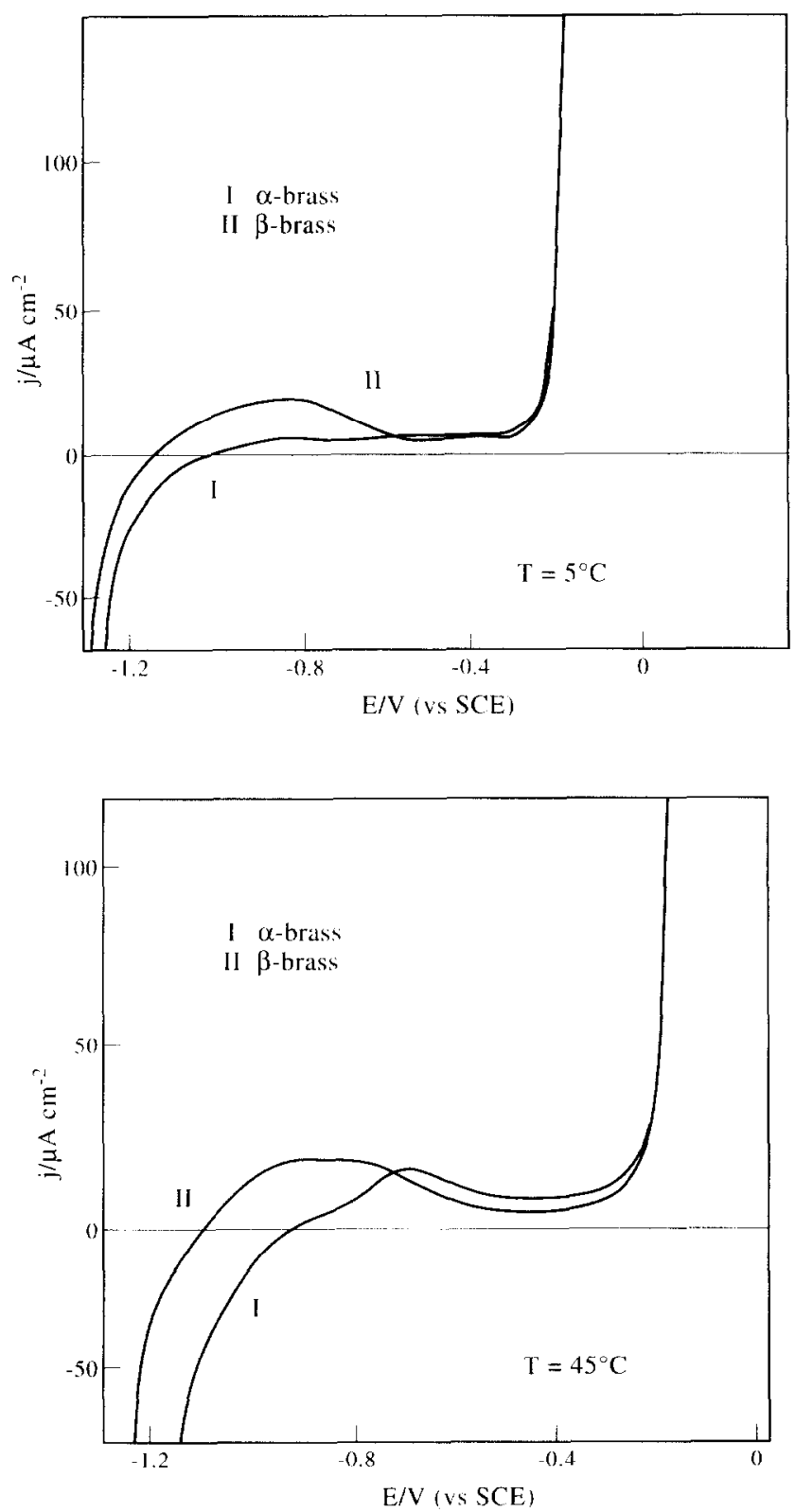

Fig. 9. Anodic polarization curves recorded at $2 \times 10^{+4} \mathrm{Vs}$, for $\alpha$-brass and $\beta$-brass in aqueous $0.5 \mathrm{M} \mathrm{NaCl}$ : (a) $T=5 \mathrm{C}$; (b) $T=45 \mathrm{C}$.

$5 \mathrm{C} \leq T \leq 25 \mathrm{C}$, but it increases markedly for $T>25 \mathrm{C}$. The relatively higher level of copper species in solution for $\alpha$-brass, as compared with $\beta$-brass at $45 \mathrm{C}$, implies zinc enrichment at the surface of $\alpha$-brass during electrodissolution. This fact can explain the decrease in pitting corrosion resistance of $\alpha$-brass at this temperature. 
Table 1. Concentration (c) of soluble $\mathrm{Cu}$ and $\mathrm{Zn}$ species and $\mathrm{Cu} / \mathrm{Zn}$ concentration ratio $(r)$ resulting from the anodic polarization of specimens at $E=0.0 \mathrm{~V}$ for $3 \mathrm{~h}$ in aqueous $0.5 \mathrm{M} \mathrm{NaCl}$, at different temperatures

\begin{tabular}{lllc}
\hline & \multicolumn{3}{c}{$T\left({ }^{\circ} \mathrm{C}\right)$} \\
\cline { 2 - 3 } & 5 & 25 & 45 \\
\hline$\alpha$-brass & & & \\
$c_{\mathrm{Cu}}(\mathrm{ppm})$ & 0.15 & 0.19 & 1.1 \\
$c_{\mathrm{Zn}}(\mathrm{ppm})$ & 5.5 & 7.7 & 23.1 \\
$r(\mathrm{Cu} / \mathrm{Zn})$ & 0.027 & 0.025 & 0.048 \\
$\beta$-brass & & & \\
$c_{\mathrm{Cu}}(\mathrm{ppm})$ & 0.14 & 0.16 & 0.54 \\
$c_{\mathrm{Zn}}(\mathrm{ppm})$ & 12.23 & 17.8 & 25.12 \\
$r(\mathrm{Cu} / \mathrm{Zn})$ & 0.011 & 0.009 & 0.021 \\
\hline
\end{tabular}

The physical picture underlying these results can be summarized as follows. The anodic layers produced on both $\alpha$-brass and $\beta$-brass are almost similar in nature in the range $5^{\circ} \mathrm{C} \leq T \leq 45^{\circ} \mathrm{C}$. When local rupture of the anodic layer takes place in the range $5^{\circ} \mathrm{C} \leq T \leq 25^{\circ} \mathrm{C}, \alpha$-brass exhibits a surface layer richer in copper than that of $\beta$-brass. But for $T>25^{\circ} \mathrm{C}$, the surface composition of both alloys tends to be the same. Then, except for the observations made in the lower temperature range, the resistance to pitting corrosion of $\alpha$-brass and $\beta$-brass becomes very similar.

\section{CONCLUSIONS}

(1) In the range $5^{\circ} \mathrm{C} \leq T \leq 45^{\circ} \mathrm{C}$, the passive layers formed on $\alpha$-brass and $\beta$-brass in plain borate-boric acid buffer and in $\mathrm{NaCl}$-containing buffer behave similarly, although the average anodic layer thickness produced under preset voltammetric conditions increases slightly with the temperature.

(2) At constant temperature and $\mathrm{NaCl}$ concentration, the value of $E_{\mathrm{b}}$ increases with the $\mathrm{Cu} / \mathrm{Zn}$ ratio in the alloy.

(3) For $\beta$-brass, the value of $E_{\mathrm{b}}$ remains almost constant in the range $5^{\circ} \mathrm{C} \leq T \leq 25^{\circ} \mathrm{C}$, and decreases slightly for $T>25^{\circ} \mathrm{C}$.

(4) For $\alpha$-brass, the value of $E_{\mathrm{b}}$ is almost constant or decreases slightly in the range $5^{\circ} \mathrm{C} \leq T \leq 25^{\circ} \mathrm{C}$ remaining close to those $E_{\mathrm{b}}$ values already reported for copper. Otherwise, for $T>25^{\circ} \mathrm{C}$, the value of $E_{\mathrm{b}}$ decreases to those values observed for $\beta$-brass.

(5) The comparable pitting corrosion behaviour of $\alpha$-brass and $\beta$-brass in $\mathrm{NaCl}$-containing buffer at $T>25^{\circ} \mathrm{C}$ can be explained by the decrease in the $\mathrm{Cu} / \mathrm{Zn}$ ratio at the surface of the $\alpha$-brass. 


\section{REFERENCES}

1. Pickering, H.W. and Wagner. C. J. Electrochem. Soc., 1967, 114, 698.

2. Newman, R.C., Shahrabi, T. and Sicradzki, K. Corros. Sci., 1988, 28, 873.

3. Scully, J.C. Met. Sci. 1978, 12, 290.

4. Gad-Allah, A.G., Abou-Romia. M.M., Badawy, M.W. and Rehan, H.H. J. Appl. Electrochem., 1991, 21, 829

5. Szklarska-Smialowska, Z. Corrosion, 1990, 46, 85 .

6. Morales, J., Fernández, G.T., Esparza, P., Gonzalez, S.. Salvarezza, R.C. and Arvia, A.J. Corros. Sci., 1995, 37, 211.

7. Morales, J., Esparza, P., Fernández. G.T., Gonzalez, S.. García. J.E., Cáceres, J., Salvarezza, R.C. and Arvia, A.J. Corros. Sci., 1995, 37, 231.

8. Figueroa, M.G., Salvarezza, R.C. and Arvia, A.J. Electrochim. Acta, 1986, 31, 665.

9. Elsner, C.I., Schilardi, P.L. and Marchiano, S.L. J. Appl. Electrochem., 1993, 23, 1181.

10. Mishima, H., Lopez de Mishima, A.B., Santos, E., De Pauli, C.P., Aumi, K. and Sato. N. Electrochim. Acta, 1991, 36, 1491.

11. de Chialvo, M.R.G., Salvarezza, R.C.. Vasquez Moll, D. and Arvia, A.J. Electrochim. Acta., 1985, 30, 1501

12. Brodd, R.J. and Leger. V.E., in The Encyclopedia of the Electrochemistry of the Elements, Vol. V. ed. A.J. Bard. Marcel Dekker, New York, 1976. p. 2.

13. Salvarezza, R.C., DeCristofaro, N., Pallotla, C. and Arvia. A.J. Electrochim. Acta, 1987, 32, 1049.

14. Morales, J., Esparza, P., Gonzalez. S., Vázquez, L., Salvarezza, R.C. and Arvia, A.J. Langmuir, 1996, 12, 500. 